\title{
REVISIONARY NOTES ON THE GENERA OF EUCHEILINI (COLEOPTERA, CARABIDAE)
}

\author{
By Hans ReIchaRdT ${ }^{1}$ \\ Departamento de Zoologia, Secretaria da Agricultura, \\ São Paulo, Brazil
}

In the course of my studies on Neotropical Carabidae I have discovered several interesting taxonomic novelties about the endemic tribe Eucheilini which seem to be important enough to be reported on. Even though I have examined the types of the species of Eucheilini which are preserved in the Muséum National d'Histoire Naturelle, Paris, in July, $1964^{2}$, it is as yet imposible to revise the tribe at the species level, since the species of Inna, one of the two genera of Eucheilini, are very poorly understood at present. Material in collections is very scarce. I hope that in the near future accumulation of enough specimens will allow a specific revision of this interesting tribe of Carabidae.

The material on which this revision is based has been borrowed (and partly also studied in loco) from the Departamento de Zoologia, São Paulo (CDZ), the Museu de la Universidad de La Plata, Argentina (MLP), the Museum of Comparative Zoology, Cambridge, Mass. (MCZ), the Muséum National d'Histoire Naturelle, Paris (MNHN) and the United States National Museum, Washington, D. C. (USNM). The loan of this interesting material is gratefully acknowledged.

The tribe and the genera included in this revision are not formally redescribed, since it seems to me that for the time being the characterization presented below is enough.

\section{Tribe Eucheilini}

Eucheilinae Bates, 1883, Biol. Centr. Amer., Col., 1 (1):168.

Periglossinae Liebke, 1929 Ent. Anz., 9:247. NEW SYNONYMY.

Euchilini; Csiki, 1932, Col. Cat., 12.4:1585; Blackwelder, 1944, Bull. U.S.N. Mus., $185: 70$.

Periglossini ; Csiki, 1932, Col. Cat., 124 :1585 ; Blackwelder, 1944, Bull. U.S.N. Mus., 185 :70.

Eucheilini; Ball, 1960, Beetles of the U.S.:164.

\footnotetext{
${ }^{1}$ Currently at the Museum of Comparative Zoology, Harvard University Manuscript received by the editor December 1, 1965.

${ }^{2}$ A trip supported by the Evolutionary Biology Committee at Harvard University; this support is gratefully acknowledged.
} 
This small Neotropical tribe includes only two genera of small, Lebiini-like Carabidae. Their systematic position has been uncertain for a long time. Even though Eucheila, the type-genus, was described as early as I829 (in Lebiini), the true relations to Helluonini were only recognized in I883, when Bates erected the subfamily Eucheilinae to incorporate Eucheila and Inna (the latter also described in Lebiini, and at first considered as related to Eucheila by Bates), and placed it in the vicinity of the Helluonini.

In 1929 Liebke described the subfamily Periglossinae for a new Central-American genus, Periglossium. From his description and illustrations of this beetle, it is evident that Periglossium is a synonym of Inna, and consequently the name Periglossinae has to be suppressed.

The characters which link the Eucheilini to the Helluonini are the strangely modified mouthparts (Figs. I-8). In spite of similarities, the Eucheilini are undoubtedly a distinct tribe, easily distinguished from the Lebiini by the completely different mouthparts and from the Helluonini by their general Lebiini-habitus, as well as by the antennae which are pubescent from the 4th segment on in Eucheilini (pubescent from base in Helluonini). The aedeagus of the Eucheilini was unknown up to now. I was able to dissect one male of Eucheila strandi (Liebke) and one of Inna boyeri (Solier) (see Figs. I I and I2). The two aedeagi are very similar, and this fact strengthens the supposed relation between the two genera. The left paramere of the aedeagus is reduced, but still present, being somewhat lobate in the two species. The genitalia of Neotropical Helluonini are also unknown, so that no comparison can be made now.

Geographic distribution: The tribe is typically Neotropical, extending from Argentina to the southern United States (Texas). No species has yet been reported from the Antilles.

\section{Key to genera}

I. Labrum convex, covering apex of mandibles, with short setae only on lateral margins (Fig. 8); lateral margins of pronotum smooth, not crenulated; pronotum with basal setae only; tarsal claws pectinate Eucheila Dejean

Labrum flat, not covering apex of mandibles, with 4 long setae on anterior margin, 2 longer ones and a series of short ones laterally (Fig. 3); lateral margins of pronotum crenulated; pronotum with basal and latero-median setae; tarsal claws simple Inna Putzeys 


\section{Eucheila Dejean}

Eucheyla Dejean, in Dejean and Boisduval, 1829, Icon. Col. Eur., $1: 60,176-$ 177 (type-species, by monotypy, Eucheyla flavilabris Dejean).

Eucheila; Dejean, 1831, Spec. gen. Col., 5:455-456; Chaudoir, 1848, Bull. Soc. Nat. Moscow, 21 (1) :124; Lacordaire, 1854, Gen. Col., 1:148.

Euchila Dejean (nec Euchila Billberg); Agassiz, 1846, Nomencl. Zool. (emmendation); Gemminger and Harold, 1868, Cat. Col.. 1:155; Csiki, 1932, Col. Cat., 124:1585; Blackwelder, 1944, Bull. U.S.N. Mus., 185:70.

The genus was originally spelled Eucheyla by Dejean, who in the original description gave the Greek derivation of the name. It is obvious that this spelling was an incorrect transliteration. Dejean himself must have realized this, and in I83I used the name Eucheila instead, without any mention of Eucheyla. According to article 32 of the International Code of Zoological Nomenclature, Eucheyla should be accepted as the "correct original spelling", since incorrect transliteration is not to be considered an inadvertent error (article 32, section a, ii). However, Eucheyla has remained unused as a senior synonym since 1829 , and must, therefore, be considered a nomen oblitum (article 23, section b). Eucheila Dejean must, therefore, be considered the correct and valid name for the genus. Eucheyla Berlese, I9I3, proposed as a subgenus of Cheyletia Haller, I884 (Arachnida, Acari, Cheyletidae) is a junior homonym of Eucheyla Dejean, and has been replaced by Neoeucheyla Radford, I950. Agassiz ( 1846 ) emmended the name to Euchila, which is, however, a junior homonym of Euchila Billberg, I 820 (Insecta, Lepidoptera).

Eucheila Dejean is easily distinguished from Inna Putzeys by the characters given in the generic key. The genus was described for a single species, flavilabris Dejean; however, material of Inna strandi Liebke from the type-locality, proves that Liebke's species is congenic with flavilabris.

\section{Key to species of Eucheila}

I. Metallic-brown species with dark brown appendages and lighter labrum; elytra 9-carinate strandi (Liebke)

Metallic-green species (sometimes very dark), with yellow appendages and labrum; elytra with vestigial carinae

flavilabris Dejean

Eucheila strandi (Liebke), new combination.

(Figs. 5-8, II )

Inna strandi Liebke, 1939, Festschr. Emb. Strand, 5:121 (type from Jatai, Brazil, in Liebke's collection; probably destroyed). 

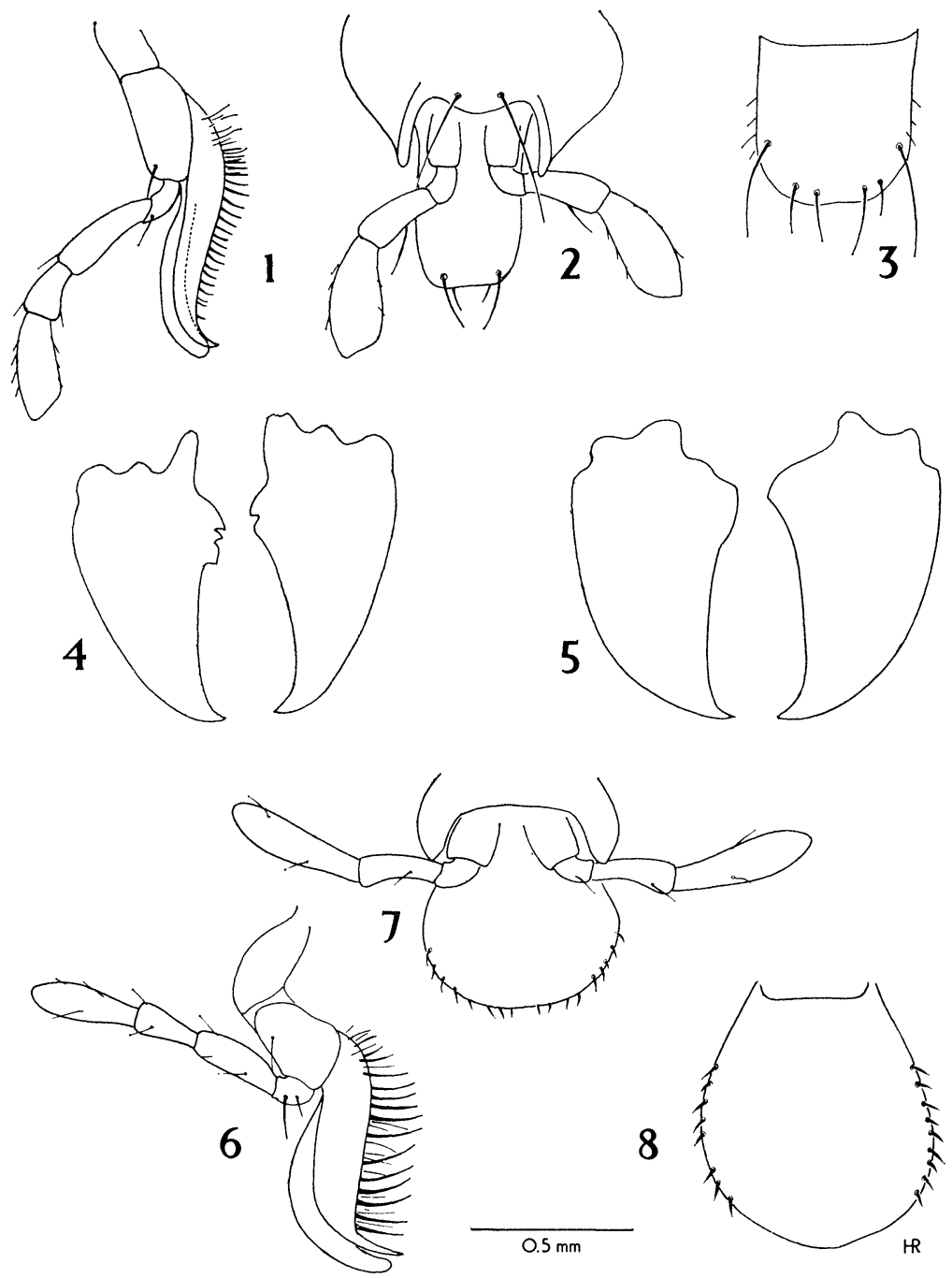

Figs, 1-4, Inna boyeri (Solier) : Fig. 1, maxilla; Fig. 2, labium; Fig. 3, labrum; Fig. 4, mandibles; Figs. 5-8, Eucheila strandi (Liebke): Fig. 5, mandibles; Fig. 6, maxilla; Fig. 7, labium: Fig. 8. labrum. 
Psyche, 1966
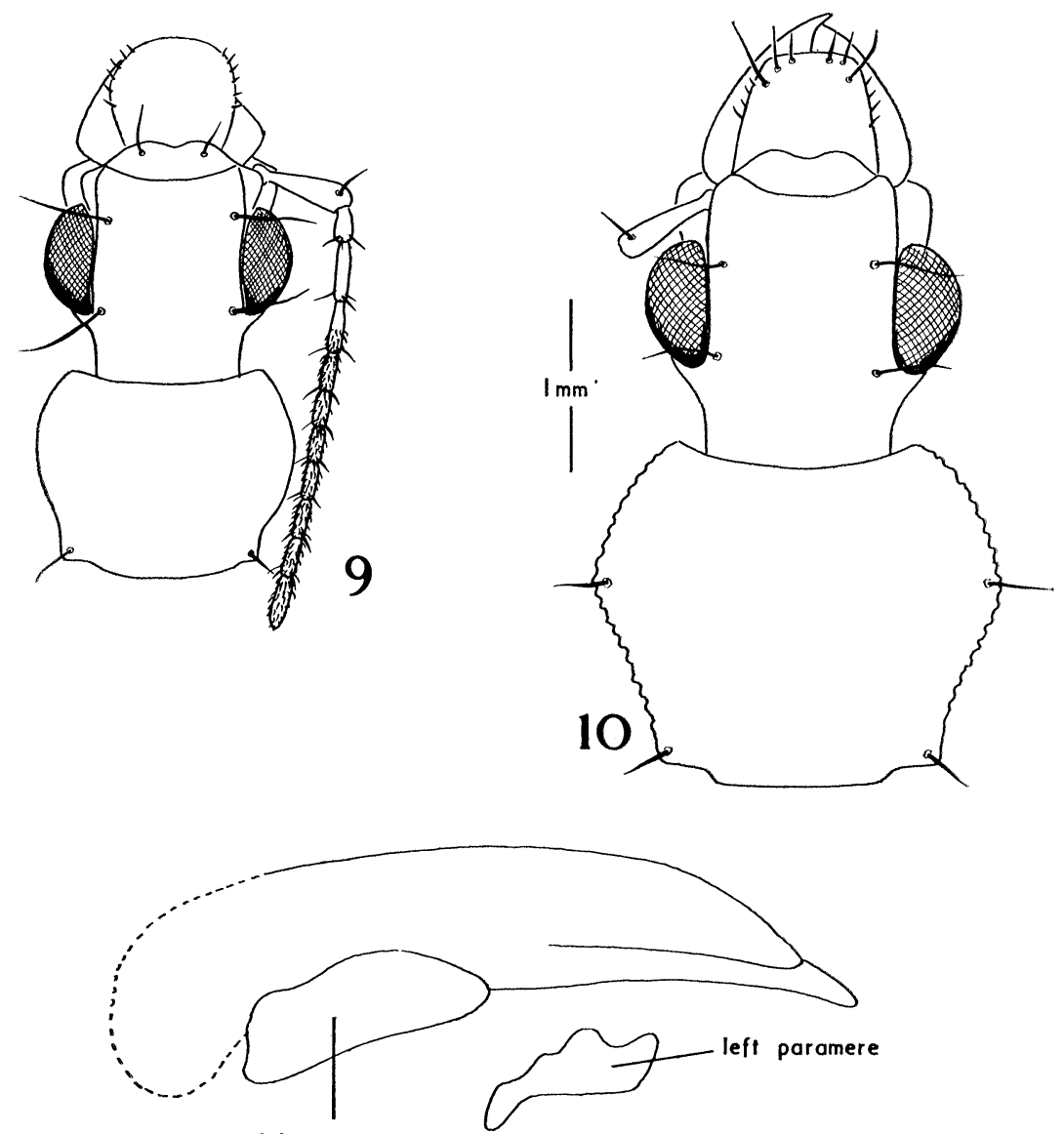

right paramere

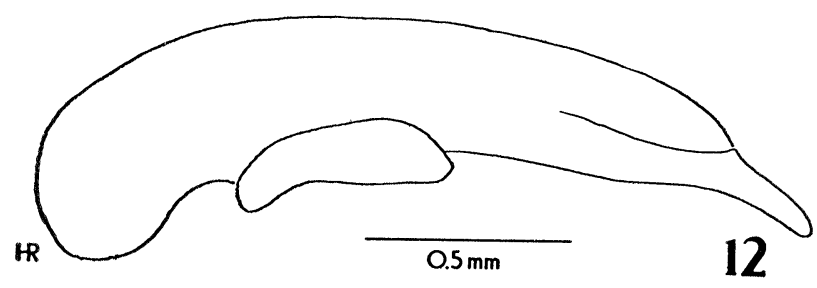

REICHARDT - EUCHEILINI
Vol. 73, Plate 1

11 
The pectinate claws, the very typical labrum and labium and the non-crenulated margin of the pronotum put this species without doubt in the same genus as flavilabris. It is easily distinguished by the different color and the well developed elytral carinae.

Examined specimens (6) : Brazil: São Paulo, Guatapará ( I ex., CDZ) ; Goiás, Jataí (3 exx., CDZ, MCZ) ; Bahia, no locality ( I ex., MNHN); Ceará, no locality ( I ex., USNM).

\section{Euchila Aavilabris Dejean}

(Fig. 9)

Eucheyla flavilabris Dejean, in Dejean and Boisduval, 1829. Icon. Col. Eur., $1: 178$, pl. 8, fig. 3 (type from "environs de Rio-Janeiro", MNHN; examined).

Eucheila flavilabris; Dejean, 1831, Spec. gen. Col., 5:456-457; Lacordaire, 1854, Gen. Col., 1, pl. 4, fig. 4; Putzeys, 1863, Mem. Soc. Sci. Liège, $18: 72$. pl. 2, figs. $75-77$.

Eucheila flavilabris is easily distinguished from strandi by the completely different color, especially that of the appendages. A few specimens are very dark, almost as brown as strandi; however, the elytral carinae are always vestigial and the appendages always yellow.

Examined specimens (I4): Brazil: Bahia, Salobro (I ex., MNHN); Minas Gerais, Matusinhos ( I ex. MNHN); Serra do Caraça ( I ex., MNHN); Rio de Janeiro, Nova Friburgo (6 exx., MNHN) ; Guanabara, Rio de Janeiro ( I ex., MNHN) ; São Paulo, Estação Biológica de Boraceia, Salesópolis (2 exx., CDZ) ; Santa Catarina, no locality ( I ex., MNHN). Argentina: Santiago del Estero, near Icaño ( I ex., MNHN).

\section{Inna Putzeys}

Inna Putzeys, 1863, Mem. Soc. Sci. Liège, 18:71 (type-species, by monotypy, Inna punctata Putzeys); Chaudoir, 1872, Rev. Mag. Zool., (2) 23 :219221 (redescription).

Periglossium Liebke, 1929, Ent. Anz., 9:246-247 (type-species. by original designation, Periglossium nevermanni Liebke). NeW synonymy.

Ten species of Inna are presently known, their distribution ranging from Argentina (atrata Dejean) to southern Texas (texana Schaeffer). My notes on the types suggest that some of the described species are synonyms, e.g., Inna costulata Chaudoir is differentiated from granulata Chaudoir only by color: costulata is coppery-metallic,

Explanation of Plate 1

Fig. 9, Eucheila flavilabris Dejean, head and pronotum; Fig. 10, Inna megala, n. sp., head and pronotum; Fig. 11, aedeagus of Eucheila strand: (Liebke); Fig. 12, aedeagus of Inna boyeri (Solier). 
while granulata is very dark brown, almost non-metallic. This color difference seems to be a very weak character, but since only the types are known, further decisions cannot be made now. It is also possible that nevermanni, from Costa Rica, is a synonym of costulata, which ranges from Colombia to Guatemala. The type of Inna nevermanni (Liebke) has probably been destroyed with part of Liebke's collection and no material is presently available from Costa Rica, so that nothing else can be said here.

The generic description of Periglossium Liebke does not differ in any respect from that of Inna Putzeys. There seems to be no reason to maintain Periglossium, which was probably described by Liebke when he did not know Inna.

Inna is easily distinguished from Eucheila by the characters given in the key.

Even though I have seen the types of most species, as mentioned above, I am presenting below new data only on two of the older species, of which material was available and could be identified. The recognition of the new species is based on comparison with the original descriptions of all the older species as well as on my notes on their types.

\section{Ina boyeri (Solier)}

(Figs. I-4, I2)

Polystichus boyeri Solier, 1835, Ann. Soc. Ent. France, 4:111 (holotype male from "Colombia", MNHN; examined).

Inna boyeri; Chaudoir, 1872, Rev. Mag. Zool., (2) 23 :241-242 (redescription).

I am referring to this species, originally described from Colombia, a series of Io specimens from Barueri in the state of São Paulo, Brazil (CDZ, MCZ), which agree with the description and my notes on the type. Inna boyeri is very similar to costulata; however, it has more densely punctate pronotum and head, and is slightly larger in size.

\section{Inna atrata (Dejean)}

Cymindis atrata Dejean, 1831. Spec. gen. Col., 5:327 (holotype from "BuenosAyres", MNHN; examined).

Inna atrata; Chaudoir, 1872, Rev. Mag. Zool., (2) 23 :243-244.

The type-specimen in the Paris Museum is very damaged: the left elytron and the left antenna are missing, as well as parts of several legs. The species is very characteristic, having a densely punctate head and being the smallest species of the genus. 
Examined specimens (3): Argentina: Buenos Aires, Buenos Aires (i ex., MLP); Isla Martin Garcia ( I ex., MLP); Misiones, no locality (I ex., MLP).

\section{Inna megala, n. sp.}

(Fig. IO)

Description: Reddish-brown, with light, almost yellow appendages; elytral margin very light brown. Head - densely punctate dorsally, with longitudinal striation on antennal tubercules; whole surface micro-reticulate. Pronotum - wider than long, slightly wider than head; densely punctate on surface, with somewhat granulate aspect; posterior angles more or less square; lateral margins turned upwards, crenulated; median line in a slight depression which continues on each side anteriorly (forming a Y). Elytra - with 8 irregularly punctured sulci; 7 discal interstices more or less smooth, convex; 8th and 9th interstices very slightly indicated only, mainly posteriorly; almost twice as wide as pronotum, less than twice as long as wide; elytral margin with setose punctures. Measurements - holotype, 3.7 $\times$ I0.3 mm; paratype, $4.1 \times 10.9 \mathrm{~mm}$.

Types: Paraguay: holotype female, Villarrica, F. Schade col. (MCZ n. 3II97); paratype female, Amambay, A. Schulze col. (CDZ).

Inna megala is very similar to planipennis Bates, which is only known from Mexico. The two species are of about the same size; planipennis has a less densely punctured head, especially between the eyes; the pronotum of megala is more transverse than that of planipennis.

Specific name: megala is derived from the Greek adjective megas, meaning large.

\section{REFERENCES}

BALL, G. E.

1960. Carabidae, in Arnett, The Beetles of the United States, pp. 55182,63 figs., Washington, D. C.

Bates, H. W.

1881-1884. Carabidae in Biologia Centrali-Americana, Coleoptera, 1, 299 pp., 13 color plates.

BLACKWELDER, R. E.

1944. Checklist of the Coleopterous Insects of Mexico, Central Amer1ca, the West Indies and South America. Part 1. Bull. U.S.N. Mus., $185: 1-88$.

\section{Chaudoir, $M$.}

" 12 Mémoire sur la famille des carabiques. Bull. Soc. Nat. Moscow, $21: 3-134$. 
1872. Descriptions d'espèces nouvelles de carabiques de la tribu des troncatipennes, et remarques synonymiques. Rev. Mag. Zool., (2) $23: 219-221$.

CsIKI, E.

1932. Carabidae, Harpalinae VII, in Coleopterorum Catalogus, pars $124: 1279-1598$.

Dejean. P. F. M. A.

1829. In Dejean and Boisduval, Iconographie et histoire naturelle des Coléoptères d'Europe, 1, 400 pp., 60 pls., Paris.

1831. Spec. gen. Col., 5, 883 pp., Paris.

Gemminger, M. and E. von Harold

1868. Catalogus Coleopterorum ..., 1, 424 pp., Monachii.

LACORDAIRE, J. T.

1854. Genera des Coléoptères . . . 1. 486 pp., Paris.

LiebKe, M.

1929. Laufkaeferstudien. VI. Ent. Anz., 9:245-247, 261-265, figs.

1939. Neue Laufkaefer. Festschr. Embr. Strand, 5:91-130, 21 figs.

Putzeys, J. A. A. H.

1863. Postscriptum ad clivinidarum monographiam atque de quibusdam alliis. Mem. Soc. Sci. Liège, $18: 1-78$, figs.

Solier, A. J. J.

1835. Description de quelques espèces nouvelles de la famille des carabiques. Ann. Soc. Ent. France, 4:111-121. 

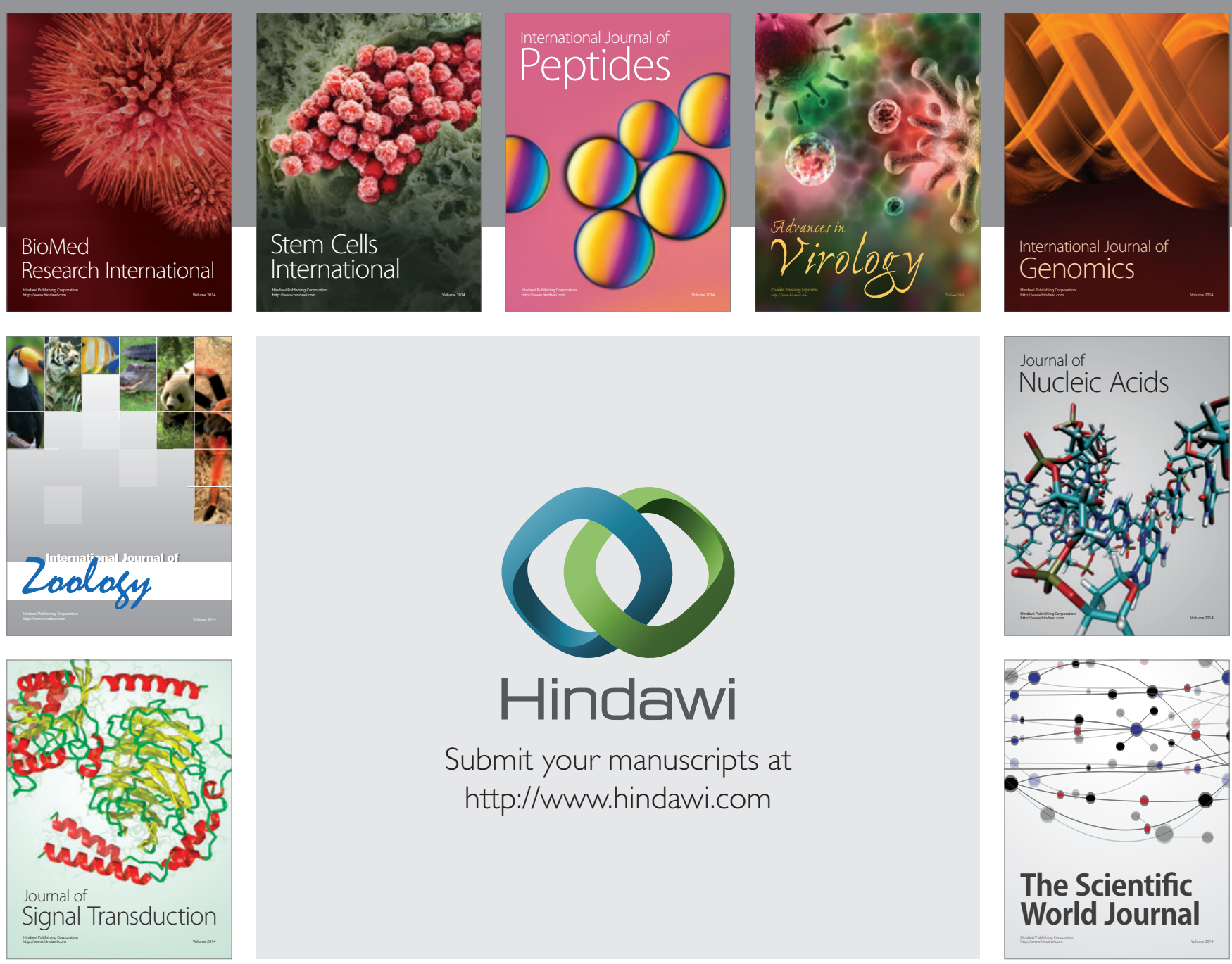

Submit your manuscripts at

http://www.hindawi.com
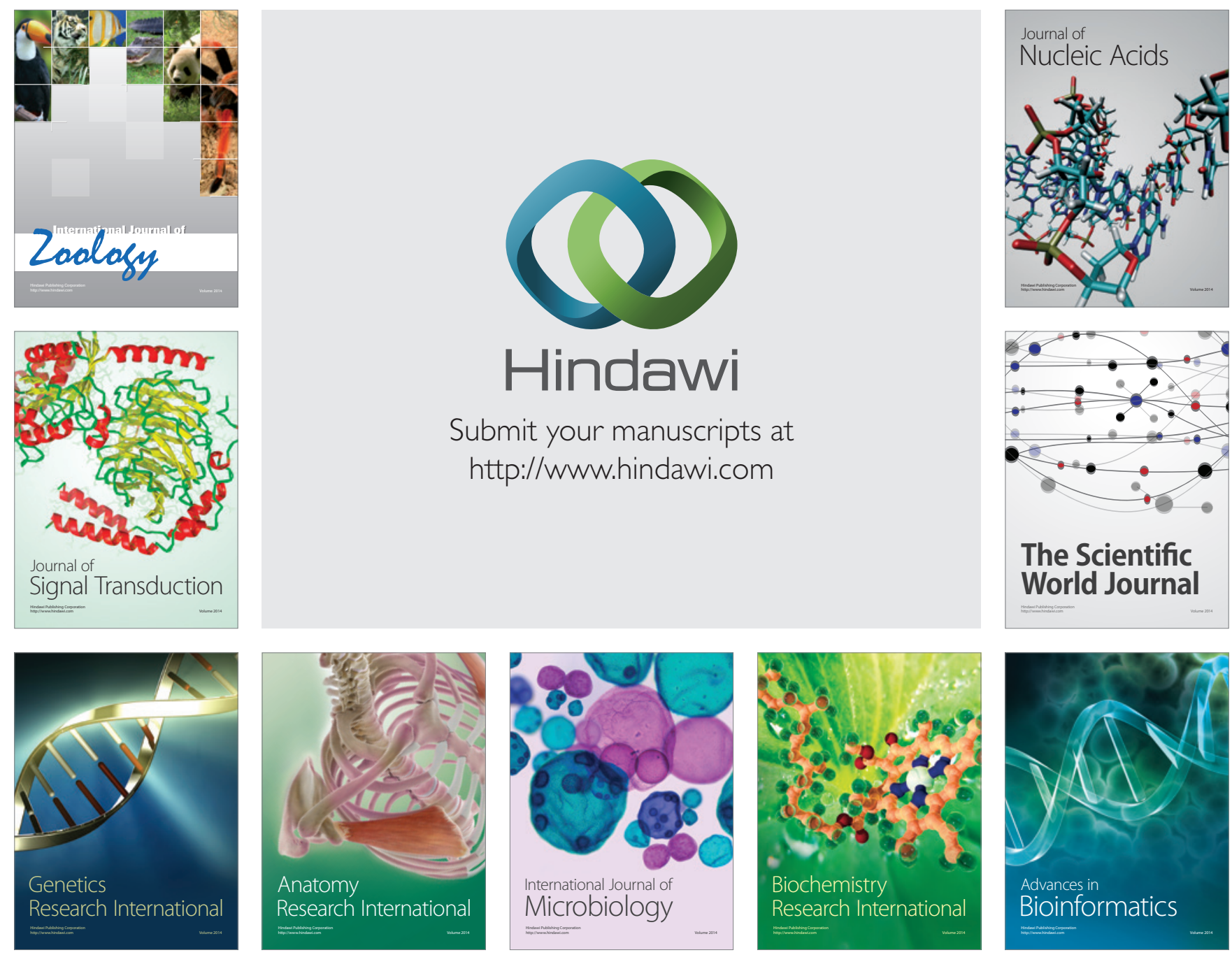

The Scientific World Journal
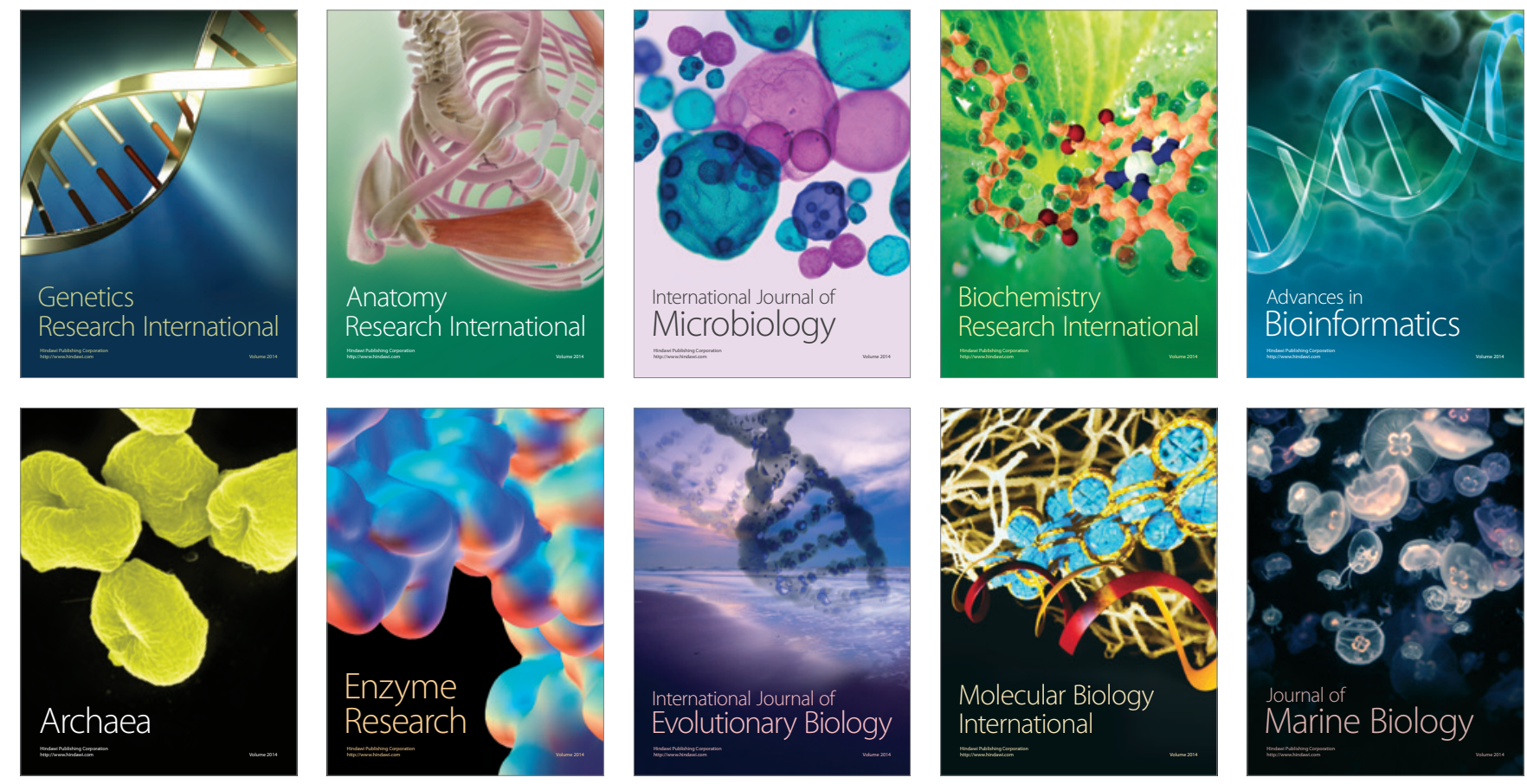